\title{
Evidence for organic phosphorus activation and transformation at the sediment-water interface during plant debris decomposition
}

\author{
Wenqiang Zhang ${ }^{\mathrm{a}}$, Xiaolei Zhu ${ }^{\mathrm{a}, \mathrm{b}}$, Xin Jin ${ }^{\mathrm{a}, \mathrm{b}}$, Xin Meng ${ }^{\mathrm{a}, \mathrm{b}}$, Wenzhong Tang ${ }^{\mathrm{a}, *}$, Baoqing Shan ${ }^{\mathrm{a}, *}$ \\ a State Key Laboratory on Environmental Aquatic Chemistry, Research Center for Eco-Environmental Science, Chinese Academy of Science, P. O. Box 2871, Beijing 100085, PR China \\ b University of Chinese Academy of Science, Beijing 100049, PR China
}

\section{H I G H L I G H T S}

- DO, pH and ORP decrease firstly and then increase until they reach stable state.

- TP, TDP and SRP increase because of PP and DOP release.

- Organic P concentrations were higher during the first decomposition period.

- Organic P may be mineralized to inorganic $\mathrm{P}$ as plant debris decomposes.

- Aquatic plant debris decomposition triggers P release from within aquatic systems.
G R A P H I C A L A B S T R A C T

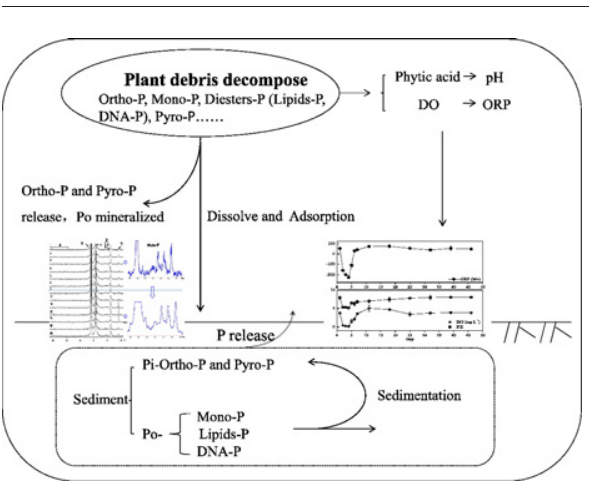

\begin{abstract}
A B S T R A C T
The processes and mechanisms through which phosphorus $(\mathrm{P})$ is released from sediment and organic $\mathrm{P}$ is transformed, induced by the decomposition of plant (duckweed (Lemma minor L.)) debris, were studied experimentally. In the simulation experiments, the dissolved oxygen concentration, $\mathrm{pH}$, and oxidation-reduction potential at the water-sediment interface first decreased rapidly. The lowest oxidation-reduction potential reached was $225.4 \mathrm{mV}$, and the solution became weakly acidic ( $\mathrm{pH}$ 5.14) and anoxic (dissolved oxygen concentration $0.17 \mathrm{mg} \cdot \mathrm{L}^{-1}$ ). The dissolved oxygen concentration, $\mathrm{pH}$, and oxidation-reduction potential then became stable. The soluble reactive $\mathrm{P}$, total dissolved $\mathrm{P}$, and total $\mathrm{P}$ concentrations in the overlying water all increased rapidly because of the particulate $P$ and dissolved organic $P$ released as the plant debris decomposed. ${ }^{31} \mathrm{P}$ NMR analysis of the solution showed that orthophosphate monoesters were the main organic P compounds in the sediment. The orthophosphate monoester and orthophosphate diester concentrations were higher during the first $7 \mathrm{~d}$ of the experiment (at 71.2 and $15.3 \mathrm{mg} \cdot \mathrm{kg}^{-1}$, respectively) than later ( 60.8 and $14.6 \mathrm{mg} \cdot \mathrm{kg}^{-1}$, respectively). The decomposition of the duckweed could have mineralized the orthophosphate monoesters and orthophosphate diesters to give orthophosphate. The results indicated that the decomposition of aquatic plant debris is a key factor in the release of $\mathrm{P}$ from sediment even when external $\mathrm{P}$ is excluded. It is therefore necessary to remove plant debris from freshwater ecosystems to control the release of $\mathrm{P}$ from plant debris and sediment.
\end{abstract}

(c) 2017 Elsevier B.V. All rights reserved.

* Corresponding authors at: State Key Laboratory on Environmental Aquatic Chemistry, Research Center for Eco-Environmental Science, Chinese Academy of Science, Beijing 100085, PR China.

E-mail addresses: wztang@rcees.ac.cn (W. Tang), bqshan@rcees.ac.cn (B. Shan). 


\section{Introduction}

Water eutrophication is a serious environmental problem around the world, especially in developing countries (Jin et al., 2005; Kagaloua et al., 2008; Pernet-Coudrier et al., 2012). Eutrophication will occur in an aquatic system if too much phosphorus (P) enters the system (Cade-Menun et al., 2006; Carpenter, 2008). The consequences of eutrophication include algal blooms, oxygen depletion, fish deaths, deterioration of the aquatic ecosystem, and increasing costs of treating water for human use (Smith and Schindler, 2008; Nyenje et al., 2010; Vörösmarty et al., 2010). It has been shown in some studies in Europe and North America that decreasing P inputs successfully stops eutrophication occurring in lakes (Schindler et al., 2016), but P contamination is still a serious problem in some Asian countries, such as China, because of increasing populations and economic activities and intensifying land use. The Chinese government has been paying more attention to environmental protection in the last $10 \mathrm{yr}$ than previously, and many projects (such as the "Chinese national water pollution control and technology management project") have been performed. Inputs of $P$ to aquatic systems in China have now been decreased, so the effects of $P$ already present in aquatic systems have become more important.

The $P$ in a freshwater system mainly comes from two sources, external P inputs and internal P (e.g., P released from sediment). Many studies have been focused on internal $P$ because sediment is both a source and a sink for P (Pant and Reddy, 2001). Changes in physicochemical conditions can affect the biogeochemical cycle of $\mathrm{P}$ at the sedimentwater interface (Reynolds, 2008; An and Li, 2009; Kraal et al., 2013; Sulu-Gambari et al., 2015). Most aquatic plants have limited growth periods, but excessive nutrient inputs can cause aquatic plants such as duckweed and algae to grow and reproduce quickly. Aquatic plant debris is not usually collected by humans because it does not have a high value for use, so the debris is allowed to decompose in situ. The decomposition of plant residues will affect the bio-cycling, retention, and release of $\mathrm{P}$, and will increase the $\mathrm{P}$ concentration in the overlying water, increasing the risk that eutrophication will occur (Cheesman et al., 2010). Decaying plant debris releases both inorganic P (Pi) and organic $\mathrm{P}$ (Po). The Po constituents can be hydrolyzed to give phosphate and provide bioavailable $\mathrm{P}$ that aquatic plants can metabolize (Suzumura and Kamatani, 1995, Bjorkman and Karl, 1994). It is therefore important that the components, concentrations, dynamics, and effects of $P$ at the sediment-water interface are studied while plant debris is decomposing.

Duckweed (Lemma minor L.) is a common aquatic plant that usually floats on the water surface. Duckweed mostly reproduces through asexual budding from a meristem at the base of the frond. Duckweed can purify water and can be used as food for fish and poultry (Zhu et al., 2010). Duckweed has a short lifecycle that is completed within several weeks. Duckweed can be used to remove pollutants from an aquatic system if it is collected at the correct time. Unfortunately, social and economic developments in China have meant that people no longer collect duckweed to feed to poultry, so large amounts of duckweed debris now remain in aquatic systems from which duckweed was previously collected (Du et al., 2011).

We hypothesized that the decomposition of duckweed will affect P concentrations and characteristics at the sediment-water interface and particularly affect the transformation of Po. Therefore, duckweed was used as a model plant to study (i) variations in the physicochemical properties of the sediment-water interface, (ii) $\mathrm{P}$ components and transformations at the sediment-water interface, and (iii) the relationships between variations in the physicochemical properties and $\mathrm{P}$ transformations during the decomposition of duckweed debris. The P components and transformations were investigated by solution P-31 nuclear magnetic resonance spectroscopy ( ${ }^{31} \mathrm{P}$ NMR).

\section{Materials and methods}

\subsection{Sample site description and sample collection}

Sediment and duckweed samples were collected from the Beiyun River, which is an important tributary of the Hai River Basin in China (Fig. 1). A large number of dams have been built on the Beiyun River and large amounts of pollutants are discharged into the river, increasing the risk of eutrophication (Pernet-Coudrier et al., 2012; Maavara et al., 2015). The sediment samples were collected in August 2015. Three surface sediment samples (about $5 \mathrm{~cm}$ deep) were collected using a Peterson grab sampler. The samples were pooled and homogenized to give a representative sample. The sample was then frozen and stored at $-4{ }^{\circ} \mathrm{C}$. The duckweed samples were collected using a diddle net (with an internal diameter of $1 \mathrm{~cm}$ ). Each sample was sealed in a plastic bag and stored at $-4{ }^{\circ} \mathrm{C}$. In the laboratory, the duckweed was carefully washed with deionized water, then dried in an oven for at least $24 \mathrm{~h}$. The dry duckweed was kept in a desiccator until it was used in the experiments.

\subsection{Experimental design and execution}

Each reactor was a beaker ( $500 \mathrm{~mL})$. Dry duckweed ( $10 \mathrm{~g})$, sediment ( $30 \mathrm{~g}$ fresh weight), and deionized water $(300 \mathrm{~mL})$ were added to each reactor. In total, 13 experiments were performed. The amounts of duckweed, sediment, and deionized water used were determined by performing a preliminary experiment. Samples were collected after 1 , $2,3,4,5,6,7,11,18,25,32,39$, and $46 \mathrm{~d}$. To allow the decomposition procedure to be studied systematically, experiments containing only duckweed (CK-D) and only sediment (CK-S) were also performed. The reactors were open to the air to simulate field conditions. The ambient temperature was $25-32{ }^{\circ} \mathrm{C}$, and this was controlled by an air conditioning system. The highest temperature was reached at about $2 \mathrm{pm}$, as is the case under natural conditions. The reactors were exposed to light for $15 \mathrm{~h}$ each day and were in the dark for $9 \mathrm{~h}$, to simulate natural conditions. An appropriate amount of distilled water was added to each reactor to replace water lost through evaporation and to ensure the overlying water volume remained constant. The surface water was stirred gently for about $1 \mathrm{~min}$ at the same time each day to simulate conditions in the riverine environment.

\subsection{Analysis of the water and sediment samples}

The physical and chemical properties of the overlying water, including the dissolved oxygen (DO) concentration, $\mathrm{pH}$, and oxidation-reduction potential (ORP), were determined using a YSI Professional Plus multiparameter instrument (YSI, Yellow Springs, OH, USA) before a sample was collected. The total P (TP), total dissolved P (TDP), and solution reactive $P(S R P)$ concentrations in the overlying water were measured using the molybdenum blue method. The dissolved organic $\mathrm{P}$ (DOP) concentration was defined as the difference between the TDP and SRP concentrations (Benitez-Nelson and Buesseler, 1999). The particulate $\mathrm{P}(\mathrm{PP})$ concentration was defined as the difference between the TP and TDP concentrations. The TP, TDP, SRP, PP, and DOP contents of a reactor were calculated by multiplying the concentrations by the surface water volume. Once the physical and chemical properties of the overlying water had been measured and a water sample had been collected, a sediment sample was carefully collected. Each sediment sample was freeze dried and subjected to ${ }^{31} \mathrm{P}$ NMR analysis. The TP content of each sediment sample was measured by heating the sample to $500{ }^{\circ} \mathrm{C}$ for $2 \mathrm{~h}$, then extracting the sample with $1 \mathrm{~mol} \cdot \mathrm{L}^{-1} \mathrm{HCl}$ for $16 \mathrm{~h}$ (Aspila et al., 1976). The Pi content of a sediment sample was determined by analyzing the $\mathrm{HCl}$ extract, and the Po content was defined as the difference between the TP and Pi contents (Aspila et al., 1976). 


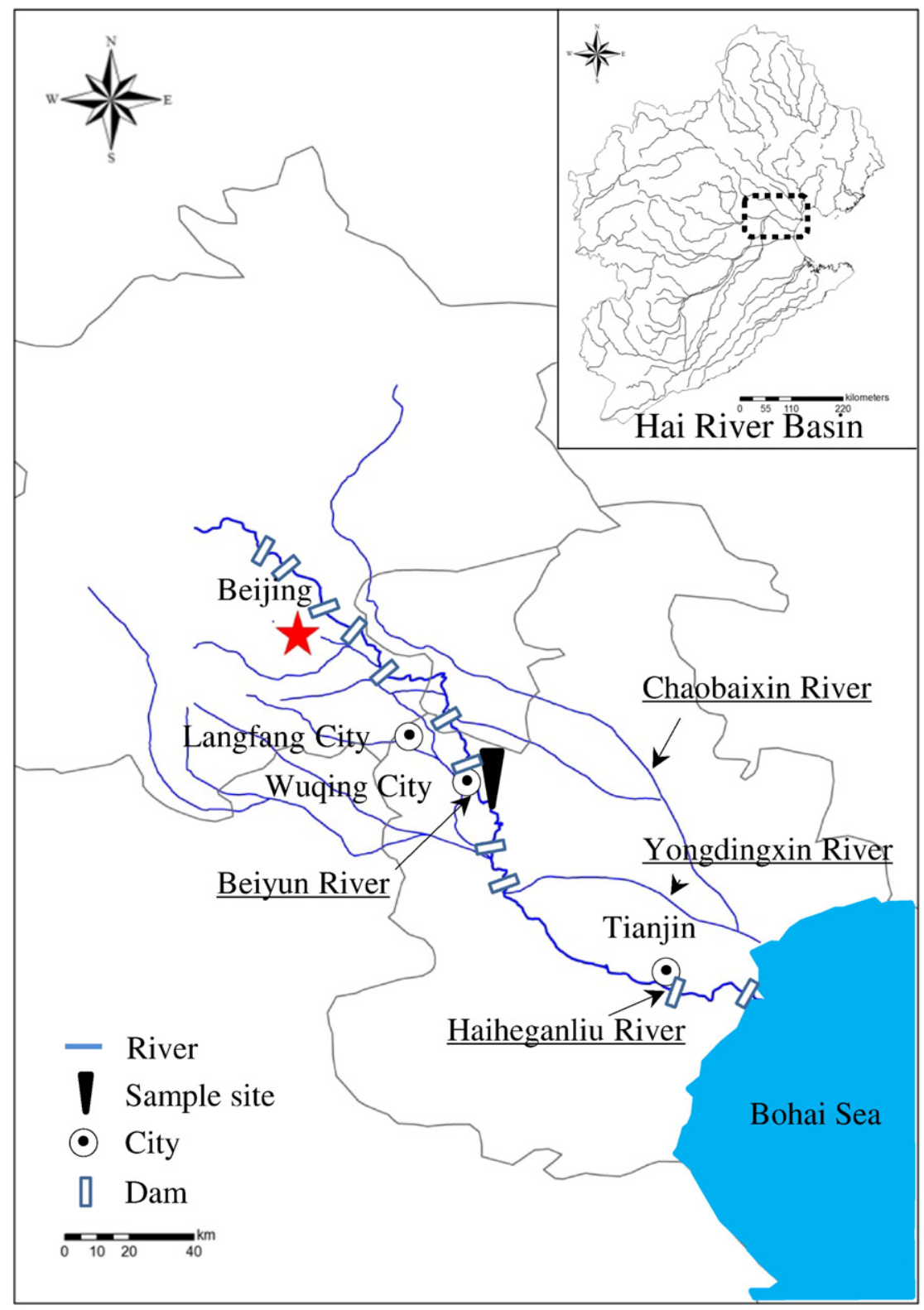

Fig. 1. The map of river systems and sample site.

2.4. NaOH-ethylenediaminetetraacetic acid extraction and ${ }^{31} \mathrm{P} N M R$ analysis

Each sediment sample $(5.0 \mathrm{~g})$ was extracted with $50 \mathrm{~mL}$ of a solution containing $0.05 \mathrm{~mol} \cdot \mathrm{L}^{-1}$ ethylenediaminetetraacetic acid (EDTA) and $0.25 \mathrm{~mol} \cdot \mathrm{L}^{-1} \mathrm{NaOH}$ for $16 \mathrm{~h}$ at room temperature (Turner et al., 2003a). An aliquot of the NaOH-EDTA extracts was used to analyze Pi (Pi in NaOH-EDTA) and TP (TP in NaOH-EDTA) using the molybdenum blue method before and after digestion by potassium persulfate $\left(\mathrm{K}_{2} \mathrm{~S}_{2} \mathrm{O}_{8}\right)$. The Po concentration in the aliquot was defined as the difference between the TP and Pi concentrations. The remaining solution was frozen, lyophilized, then subjected to ${ }^{31} \mathrm{P}$ NMR analysis. It has been shown in some studies that freezing an extract does not alter the P composition (Hupfer et al., 1995; Hupfer et al., 2004).

Each lyophilized extract $(0.3 \mathrm{~g})$ was re-dissolved in $0.6 \mathrm{~mL} \mathrm{D}_{2} \mathrm{O}$ and $0.1 \mathrm{~mL} 10 \mathrm{~mol} \cdot \mathrm{L}^{-1} \mathrm{NaOH}$, then the solution was ultrasonicated for $30 \mathrm{~min}$ and allowed to equilibrate for $5 \mathrm{~min}$. An aliquot of $2 \%(\mathrm{v} / \mathrm{v})$ bicarbonate buffered dithionite $\left(0.11 \mathrm{M} \mathrm{NaHCO}_{3}\right.$ and $\left.0.11 \mathrm{M} \mathrm{Na}_{2} \mathrm{~S}_{2} \mathrm{O}_{4}\right)$ was added to the extract to decrease interferences caused by paramagnetic ions such as $\mathrm{Fe}$ and $\mathrm{Mn}$. The supernatant was centrifuged at
$14000 \mathrm{rpm}$ for $15 \mathrm{~min}$, then transferred to a $5 \mathrm{~mm}$ NMR tube (Turner et al., 2003b; Cade-Menun et al., 2006; Zhang et al., 2013). Solution ${ }^{31} \mathrm{P}$ NMR spectra of the extracts were obtained using a Bruker $400 \mathrm{MHz}$ spectrometer (Bruker, Billerica, MA, USA) operated at $129.53 \mathrm{MHz}$ and $25^{\circ} \mathrm{C}$. A $90^{\circ}$ observation pulse, a relaxation delay of $3 \mathrm{~s}$, and an acquisition time of $0.6 \mathrm{~s}$ were used. The T1 relaxation times were not explicitly determined, but a T1 relaxation time of $3 \mathrm{~s}$ is considered to be adequate to obtain quantitative spectra for the various $\mathrm{P}$ species that were analyzed in the presence of Fe and Mn (Cade-Menun et al., 2002; McDowell et al., 2006). Spectra were acquired for around $8 \mathrm{~h}$ at the Beijing NMR center. Chemical shifts were recorded relative to an $85 \% \mathrm{H}_{3} \mathrm{PO}_{4}$ standard ( $\delta=0 \mathrm{ppm}$ ). Signals were assigned to P species based on published data (Turner et al., 2003b; Cade-Menun, 2005). The peak areas were calculated by visually inspecting the peaks and using an automated peak analysis tool. The contributions of different P-compound groups (orthophosphate (ortho-P), phosphonates, pyrophosphate (pyro-P), orthophosphate monoesters (mono-P) (myo-inositol phosphate and scyllo-inositol phosphate), and orthophosphate diesters (diester-P) (deoxyribonucleic acid (DNA-P) and phospholipid (lipid$\mathrm{P})$ )) were calculated relative to the TP concentrations in the $\mathrm{NaOH}-$ 
EDTA extracts determined using the molybdenum blue method. The peak areas were calculated by integrating spectra processed using $7 \mathrm{~Hz}$ line broadening for all of the spectra and using $2 \mathrm{~Hz}$ line broadening for particular spectra (such as for the mono-P region and diester-P region) using the manual calculation function in NUTS 2000 edition software (Acorn NMR, Livermore, CA, USA). Some peaks in the mono$P$ region could have been degradation products of diester-P compounds, such as $\alpha$ - and $\beta$-glycerophosphate (produced through the degradation of lipid-P). Therefore, the mono-P and diester-P concentrations were corrected, adding $\alpha$ - and $\beta$-glycerophosphate to the diester-P to give the total diester-P concentration (Liu et al., 2015; Schneider et al., 2016).

\subsection{Statistical analysis}

The data were analyzed using SPSS 19.0 for Windows software (IBM, Armonk, NY, USA) and OriginPro 8.5 software (OriginLab, Northampton, MA, USA). All analyses were performed using standard procedures in Microsoft Excel software (Microsoft, Redmond, WA, USA). All of the data were tested and found to fit the normal distribution.

\section{Results}

\subsection{Physicochemical properties of the water}

The $\mathrm{pH}$ values, DO concentrations, and ORPs that were found are shown in Fig. 2. The pH, DO concentration, and ORP initially increased and then decreased. The initial $\mathrm{pH}$ value was 7.89 , then the $\mathrm{pH}$ decreased as the experiment proceeded. The $\mathrm{pH}$ reached a minimum on day 4 , then increased and stabilized at $\mathrm{pH} 8$ from day 25 . The initial DO concentration was $3.75 \mathrm{mg} \cdot \mathrm{L}^{-1}$. The concentration decreased dramatically in first three days, to $0.43,0.23$, and $0.17 \mathrm{mg} \cdot \mathrm{L}^{-1}$ on days 1 , 2 , and 3, respectively, then the concentration increased to around $3.80 \mathrm{mg} \cdot \mathrm{L}^{-1}$ and remained stable. The ORP was high $(53.7 \mathrm{mV})$ at the beginning of the experiment, and decreased sharply (to $-225.4 \mathrm{mV}$ ) once the experiment began. The ORP increased on day 5 , and finally stabilized at around $50 \mathrm{mV}$. The $\mathrm{pH}$ values, DO concentrations, and ORPs varied more in the treatment experiments than in the CK-D and CK-S experiments (see Supporting Information Figs. 1 and 2). The pH, DO concentration, and ORP changed less in the CK-D experiment than in the treatment experiments, and the $\mathrm{pH}, \mathrm{DO}$ concentration, and ORP ranges were $\mathrm{pH} 5.44-7.69,0.37-3.76 \mathrm{mg} \cdot \mathrm{L}^{-1}$, and -185.4 to $65.7 \mathrm{mV}$, respectively. The physicochemical properties of the river water were monitored between January and December 2015, and the $\mathrm{pH}, \mathrm{DO}$ concentration, and ORP values were $\mathrm{pH} 8.49 \pm 0.48,2.47 \pm$ $2.38 \mathrm{mg} \cdot \mathrm{L}^{-1}$, and $28.95 \pm 18.31 \mathrm{mV}$.

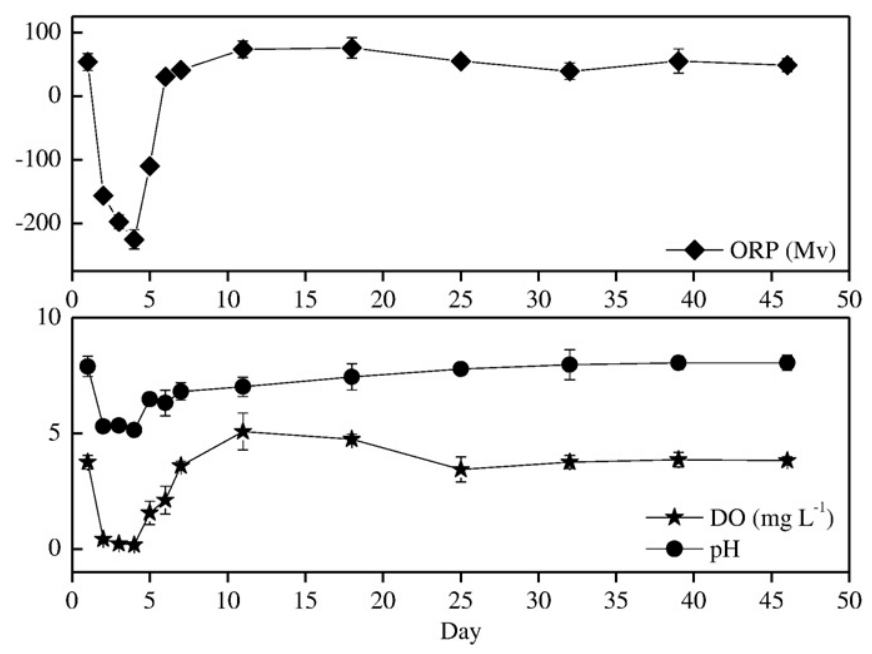

Fig. 2. The variation of physical-chemical properties at the sediment-water interface.

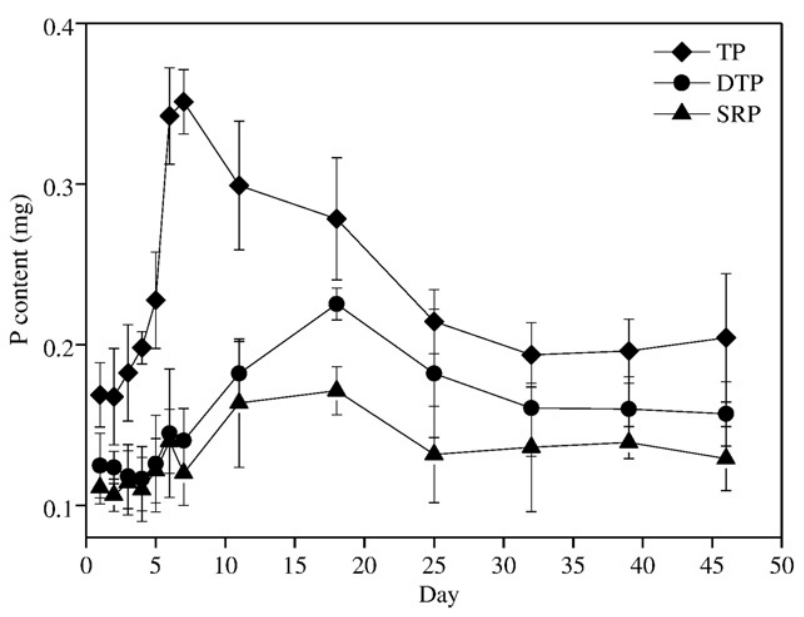

Fig. 3. The variation of content of the $P$ in the surface water during the experiment.

\subsection{P content of the water}

The P contents of the surface water samples followed the same trends, as shown in Fig. 3. The mean TP, TDP, and SRP contents increased slightly at the beginning of the experiment, then increased dramatically, and then decreased. The initial TP, TDP, and SRP contents were 0.17 , 0.12 , and $0.11 \mathrm{mg}$, respectively. The TP, TDP, and SRP contents increased as the plant debris decomposed. The contents dramatically increased after four days, and the highest TP, TDP, and SRP contents were $0.35 \mathrm{mg}$ (on day 7 ), $0.23 \mathrm{mg}$ (on day 18 ), and $0.17 \mathrm{mg}$ (on day 18 ), respectively. The TP, TDP, and SRP contents were higher in the treatment experiments than in the CK-S and CK-D experiments (see Supporting Information Fig. 3). Compared with the treatment experiments, the TP, TDP, and SRP contents of the surface water in the CK-S and CK-D experiments did not follow any clear trends. The TP, TDP, and SRP contents were highest on day 7 , at $0.15,0.14$, and $0.12 \mathrm{mg}$, respectively. The PP and DOP contents were defined as the differences between the TP and TDP contents and between the TDP and SRP contents, respectively. The PP and DOP contents of the surface water in the treatment experiments are shown in Fig. 4. The DOP content increased between days 1 and 7 , and ranged from 0.044 to $0.211 \mathrm{mg}$, then decreased until it reached $0.3 \mathrm{mg}$. The PP content increased more slowly than did the DOP content. The highest PP content $(0.054 \mathrm{mg})$ was reached on day 18 , then it decreased until it reached around $0.2 \mathrm{mg}$.

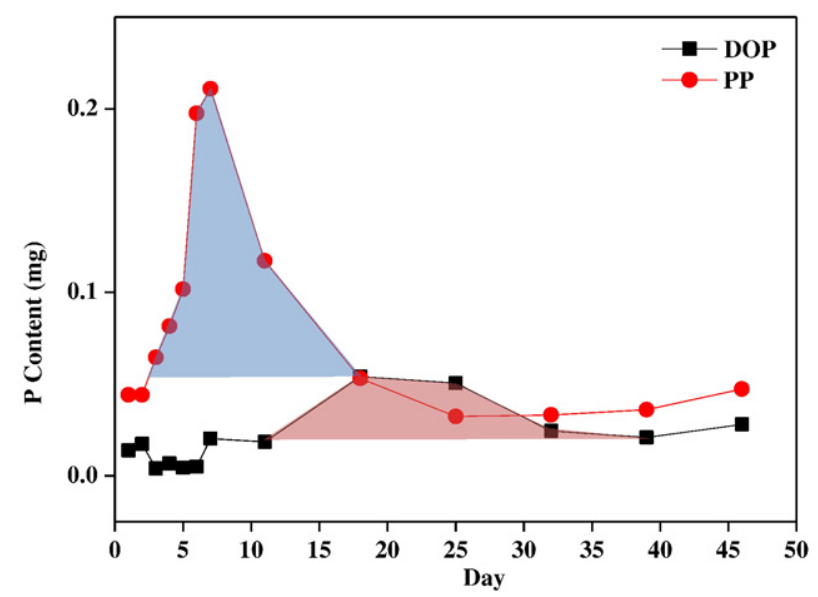

Fig. 4. The variation of PP and DOP in the water in the plant debris decomposition period. 


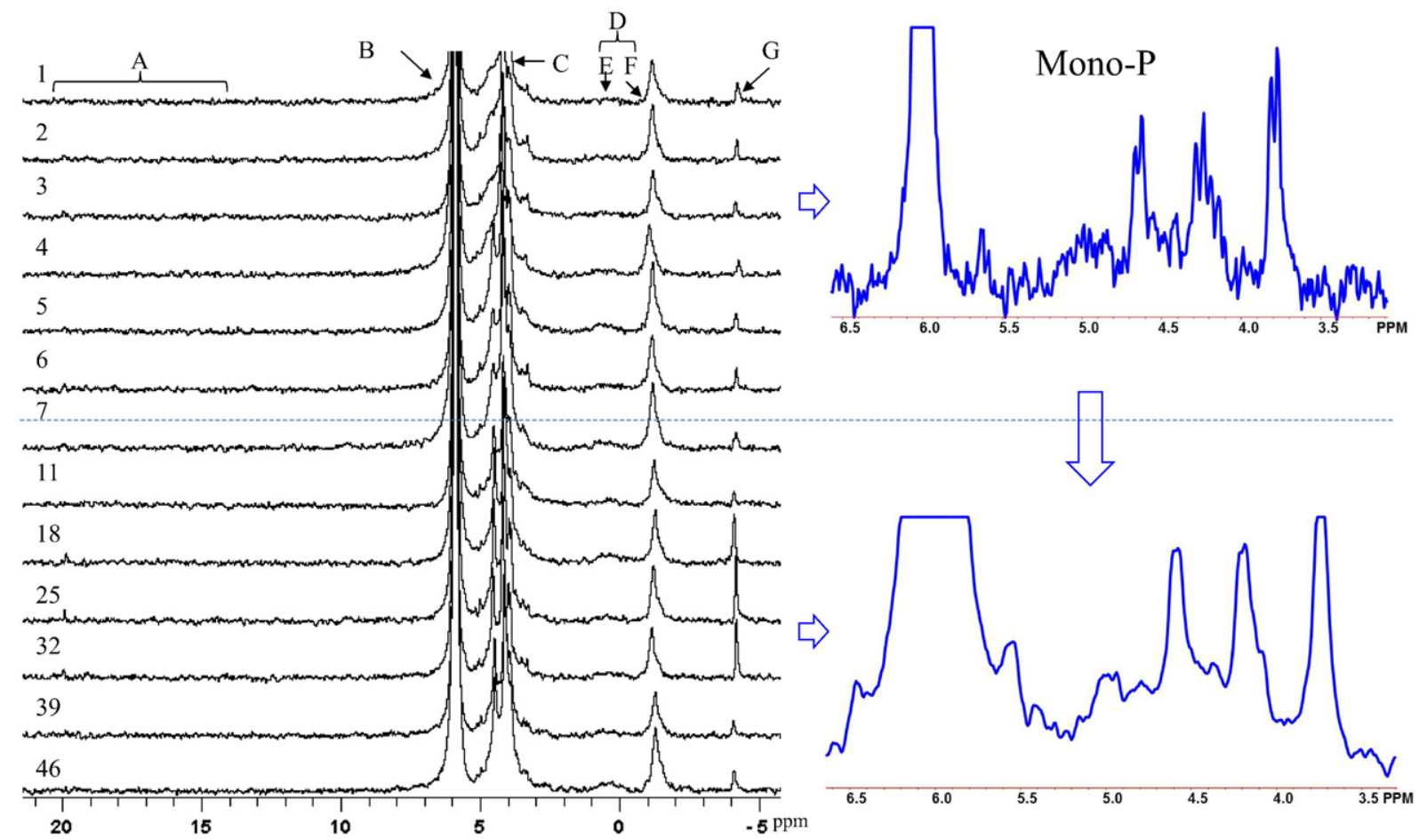

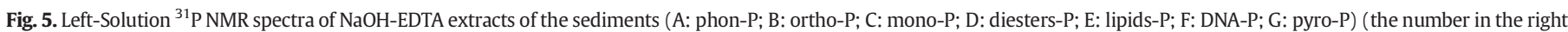
represent the sample time); right-compare of the region of mono-P in the first (up) to second (down) decomposing period.

\subsection{Solution ${ }^{31} P$ NMR spectra of the NaOH-EDTA extracts of the sediment samples}

The NMR spectra of the sediment samples are shown in Fig. 5. Six ${ }^{31} \mathrm{P}$ NMR peaks were found in the NaOH-EDTA extracts. All of the NMR spectra contained peaks in the areas indicating the presence of phosphonates (20 ppm), ortho-P (6-7 ppm), mono-P (4-6 ppm), lipid-P (1-3 ppm), DNA-P (0 ppm), and pyro-P ( -3.5 to $-4.5 \mathrm{ppm})$ (Turner et al., 2003b; Cade-Menun, 2005; Cade-Menun et al., 2006).

The concentrations and relative distributions of the different $P$ compound groups are presented in Table 1 . The Po concentrations in the $\mathrm{NaOH}-\mathrm{EDTA}$ extracts were $63.8-101.8 \mathrm{mg} \mathrm{kg}^{-1}$, and the recoveries were $42 \%-69 \%$. Ortho-P were the dominant $\mathrm{P}$ compounds in the
NaOH-EDTA sediment extracts, the concentrations being 150.3$91.6 \mathrm{mg} \cdot \mathrm{kg}^{-1}$ and the contributions to the TP concentrations being $60 \%-72 \%$. The concentrations of pyro-P, another Pi component, were 1.31 - to $4.35 \mathrm{mg} \cdot \mathrm{kg}^{-1}$, i.e., much lower than the ortho-P concentrations. The pyro-P concentrations contributed $0.5 \%-1.5 \%$ of the TP concentrations. Mono-P was the dominant $\mathrm{Po}$ in the NaOH-EDTA sediment extracts, the concentrations being $50.8-84.5 \mathrm{mg} \cdot \mathrm{kg}^{-1}$ and the contributions to the TP concentrations being $21 \%-33 \%$. The DNA-P and lipid-P concentrations were $9.6-15.3$ and $1.3-5.4 \mathrm{mg} \cdot \mathrm{kg}^{-1}$, respectively, and the DNA-P and lipid-P contributions to the TP were 3.6\%$5.9 \%$ and $0.5 \%-2.1 \%$, respectively. The phosphonate concentrations were $0.5-0.7 \mathrm{mg} \cdot \mathrm{kg}^{-1}$, and the contributions to the TP concentrations were $0.19 \%-0.29 \%$.

Table 1

Concentrations $s^{\mathrm{a}}$ of $\mathrm{P}$ compounds in $\mathrm{NaOH}$-EDTA extracts of the sediments determined by solution ${ }^{31} \mathrm{P}$ NMR.

\begin{tabular}{|c|c|c|c|c|c|c|c|c|c|c|}
\hline \multirow[t]{2}{*}{ Time (day) } & \multirow[t]{2}{*}{$\mathrm{TP}$} & \multirow[t]{2}{*}{ Po (\%) } & \multicolumn{2}{|l|}{$\mathrm{Pi}$} & \multicolumn{6}{|l|}{ Po } \\
\hline & & & \multicolumn{8}{|c|}{$\mathrm{mg} \cdot \mathrm{kg}^{-1}$} \\
\hline 1 & 255.7 & $80.7(62)^{b}$ & $172.6(67)^{\mathrm{c}}$ & $2.53(1.0)$ & $18.4(7.2)$ & $21.2(8.3)$ & $26.5(10.4)$ & $1.3(0.5)$ & $13.1(5.1)$ & n.d \\
\hline 2 & 251.3 & $87.5(68)$ & $162.2(65)$ & $1.59(0.6)$ & $22.5(9.1)$ & $22.5(9.1)$ & $26.9(10.8)$ & $2.2(0.9)$ & $13.4(5.3)$ & n.d \\
\hline 3 & 245.6 & $77.9(61)$ & $165.6(67)$ & $1.56(0.6)$ & $23.6(9.7)$ & $25.3(10.4)$ & $14.3(5.9)$ & $2.9(1.2)$ & $11.8(4.8)$ & $0.6(0.22)$ \\
\hline 4 & 225.9 & $74.1(48)$ & $150.5(67)$ & $1.31(0.6)$ & $18.7(8.2)$ & $27.9(12.2)$ & $12.7(5.6)$ & $2.7(1.2)$ & $12.1(5.4)$ & n.d \\
\hline 5 & 260.7 & $101.8(61)$ & $157.5(60)$ & $1.43(0.5)$ & $28.9(10.9)$ & $25.1(9.5)$ & 30.5 (11.6) & $3.5(1.4)$ & $13.8(5.3)$ & n.d \\
\hline 6 & 246.2 & $94.3(69)$ & $150.3(61)$ & $1.67(0.7)$ & $27.1(11.1)$ & $26.2(10.7)$ & $27.2(11.2)$ & n.d. & $13.7(5.6)$ & n.d \\
\hline 7 & 241.1 & $89.2(62)$ & $150.3(62)$ & $1.63(0.7)$ & $37.1(15.3)$ & $31.7(13.1)$ & $4(1.6)$ & $3.1(1.3)$ & $13.3(5.5)$ & n.d \\
\hline 11 & 241.1 & $75.1(59)$ & $164.8(68)$ & $1.25(0.5)$ & $26.3(11.1)$ & $24.8(10.5)$ & $10.5(4.4)$ & $2.6(1.1)$ & $10.9(4.5)$ & n.d \\
\hline 18 & 265.9 & $80.9(60)$ & $180.1(68)$ & $4.35(1.6)$ & $22.5(8.4)$ & $28.3(10.6)$ & $13.2(5.0)$ & $5.2(1.9)$ & $11.7(4.4)$ & $0.6(0.22)$ \\
\hline 25 & 266.5 & $70.5(52)$ & $191.6(72)$ & $3.95(1.5)$ & $27.4(10.3)$ & $26.3(9.9)$ & $5(1.9)$ & $2.1(0.8)$ & $9.7(3.6)$ & $0.5(0.19)$ \\
\hline 32 & 246.9 & $63.8(42)$ & $178.8(72)$ & $3.66(1.5)$ & $22.3(9.2)$ & $22.7(9.4)$ & $5.8(2.4)$ & $3.3(1.3)$ & $9.6(3.9)$ & $0.7(0.29)$ \\
\hline 39 & 261.4 & $77.6(57)$ & $182.2(70)$ & $1.62(0.6)$ & $25.6(9.7)$ & $27.7(10.4)$ & $13(4.9)$ & n.d. & $11.3(4.3)$ & n.d \\
\hline 46 & 261.4 & $84.5(58)$ & $174.7(67)$ & $2.38(0.9)$ & $24.4(9.2)$ & $26.7(10.1)$ & $12.5(4.7)$ & $5.4(2.1)$ & $15.3(5.9)$ & n.d \\
\hline
\end{tabular}

n.d. not detected.

a The value was calculated from the concentration in the NaOH-EDTA extract and the dry weight.

b The proportion of Po in NaOH-EDTA extraction to total Po in sediments (\%).

c The proportion of individual $\mathrm{P}$ fraction to total $\mathrm{P}$ in $\mathrm{NaOH}-\mathrm{EDTA}$ extraction. 


\section{Discussion}

\subsection{Release of $P$ when duckweed debris decomposed}

The decomposition of plant debris will affect the bio-cycling, retention, and release of nutrients (Cheesman et al., 2010). Plant debris decomposition is often divided into three phases, (1) leaching of the soluble components, (2) microbial degradation of organic matter and subsequent leaching of hydrolyzed substances, and (3) the physical, biological, and chemical fragmentation of refractory materials as degradation continues (Valiela et al., 1985; DeBusk and Reddy, 2005). In some studies it has been found that the first phase is faster than the second and third phases, each taking between a few days and some weeks. Soluble organic compounds, such as sugars and organic acids, and minerals (e.g., $\mathrm{K}, \mathrm{Ca}$, and $\mathrm{Mg}$ ) will be lost during the first phase (Corstanje et al., 2006). Residual $\mathrm{N}$ and $\mathrm{P}$ will be released during the second and third phases. Plant debris degradation is mediated by extracellular enzymes (Chróst, 1991). In this study, the decomposition of plant debris induced changes in the physicochemical characteristic of the surface water. According to the changes in the physicochemical properties, the duckweed debris was decomposed fully in 46 days, phase one occurring between days 1 and 7, phase two between days 8 and 19, and phase three between days 20 and 46 .

Variations in the physicochemical properties caused by plant debris decomposing will induce $\mathrm{P}$ to be released and transformed at the sediment-water interface. The $\mathrm{pH}, \mathrm{DO}$ concentration, and ORP decreased dramatically in the first five days of the experiment, then increased as the plant debris decomposition process proceeded. The mean DO concentration in the river water was lower than the mean DO concentration in the water samples from the experiment, and the mean $\mathrm{pH}$ of the river water was higher than the mean $\mathrm{pH}$ of the water samples from the experiment. The mean ORP of the water samples from the experiment was lower than the mean ORP of the river water. The DO concentration positively correlated with the TDP and SRP concentrations $\left(R^{2}=0.769\right.$ and 0.731 , respectively; $p<0.01$ for both). The $\mathrm{pH}$ also positively correlated with the TDP concentration $\left(\mathrm{R}^{2}=0.581 ; p<0.05\right)$. This indicated that variations in the physicochemical characteristics (i.e., the $\mathrm{pH}, \mathrm{DO}$ concentration, and ORP) were the main causes of changes in the P concentrations and characteristics in the surface water (Table 2). The decomposition of the duckweed debris will have induced changes in the $\mathrm{pH}, \mathrm{DO}$ concentration, and ORP and caused $\mathrm{P}$ to be released. Changes in the $\mathrm{PH}, \mathrm{DO}$ concentration, and ORP will also have caused $\mathrm{P}$ in the sediment to be released and transformed. Large amounts of $\mathrm{P}$ (including TP, TDP, and SRP) were released in the CK-D experiment because of the duckweed debris decomposing. However, the TP, TDP, and SRP contents were higher in the treatment experiments than in the CK-D experiment, indicating that the decomposition of duckweed debris in the duckweed-sediment-water system caused $P$ to be released from both the duckweed debris and the sediment. P would have been released from the sediment because of the physicochemical changes caused by the duckweed debris decomposing (Table 3).

Table 2

Pearson correlation coefficients for physicochemical characteristics and $\mathrm{P}$ in the surface water.

\begin{tabular}{lllllll}
\hline & TP & DTP & SRP & DO & pH & ORP \\
\hline TP & 1 & 0.350 & 0.506 & 0.353 & 0.007 & 0.417 \\
DTP & & 1 & $0.906^{\mathrm{b}}$ & $\mathbf{0 . 7 6 9}^{\mathrm{b}}$ & $\mathbf{0 . 5 8 1}^{\mathrm{a}}$ & $\mathbf{0 . 7 0 6}^{\mathrm{b}}$ \\
SRP & & & 1 & $\mathbf{0 . 7 3 1}^{\mathrm{b}}$ & 0.461 & $\mathbf{0 . 6 5 9}^{\mathrm{a}}$ \\
DO & & & & 1 & $0.865^{\mathrm{b}}$ & $0.946^{\mathrm{b}}$ \\
pH & & & & & 1 & $0.877^{\mathrm{b}}$ \\
ORP & & & & & & 1 \\
\hline
\end{tabular}

The significance of bold in the table indicate higher correlation.

a Correlation is significant at the 0.05 level (2-tailed).

b Correlation is significant at the 0.01 level (2-tailed).
Table 3

Compare of $\mathrm{P}$ in $\mathrm{NaOH}-\mathrm{EDTA}$ extracts in the sediment during different periods.

\begin{tabular}{lllll}
\hline Period (day) & Ortho-P & Mono-P & Diesters-P & Pyro-P \\
\hline Decompose period (1-7) & 158.4 & 71.2 & 15.3 & 1.68 \\
Post-decompose period (11-46) & 178.7 & 60.8 & 14.6 & 2.87 \\
ANOVA & $p<0.01$ & $p<0.05$ & $p>0.05$ & $p<0.05$ \\
\hline
\end{tabular}

ANOVA, one-way analysis of variance. The result of ANOVA is between different period in the experiment $(n=13)$.

The amounts of different $P$ species released during the experiment followed different patterns. The TP content of the surface water increased dramatically at the beginning of the experiment, but the TDP and SRP contents were much lower than the TP content. The TDP and SRP contents of the surface water were both around $0.1 \mathrm{mg}$, but the TP content was $0.4 \mathrm{mg}$. The maximum TP content occurred on day 7 , and then the content decreased. The maximum TDP and SRP contents occurred around day 19. As is shown in Fig. 4, most of the increase in the TP content of the surface water at the beginning of the experiment was caused by the PP content increasing because PP was released from the decomposing duckweed debris. The plant debris continued to decompose after the first decomposition phase finished. Some of the PP was sorbed by the sediment, and some of the PP in the surface water became DOP (some of the DOP may have been directly released from the decomposing plant debris). As the experiment proceeded, the TP content of the sediment decreased because PP was sorbed by the sediment. Analysis of the whole procedure indicated that the P contents of both the surface water and sediment increased as the plant debris decomposed. PP was found to be an important "carrier" during the decomposition of the plant debris.

\section{2. $P$ variations in the sediment}

The decomposition of plant debris can increase the P concentration in sediment. Plant tissues contain large amounts of Po, such as DNA-P, lipid-P, and ribonucleic acid (Turner et al., 2005b). The Po in plant tissues will be released when the tissues decompose (Cheesman et al., 2010). In the experiment, mono-P and diester-P were the main Po species found in the sediment. Mono-P are the dominant Po species in plant seeds, and they are very stable (Turner et al., 2003a). Diester-P, such as DNA-P and lipid-P, are mixtures of numerous compounds with different labilities (Turner et al., 2005a). The mono-P and diester-P in plant debris in sediment are released as the debris decomposes. Most of the mono-P and diester-P will be in PP, and will be sorbed by the sediment in an aquatic system and increase the $P$ content of the sediment.

We divided the experiment into two periods, the first period being from day 1 to day 7 and the second from day 11 to day 46 . The mono$P$ and diester-P contents of the sediment increased during the first period (when the plant debris decomposed quickly), and the mean contents were 71.2 and $15.33 \mathrm{mg} \cdot \mathrm{kg}^{-1}$, respectively. The Po compounds and contents in the sediment changed as the experiment proceeded. The mono-P and diester-P contents were higher during the first period (when they were 71.2 and $15.3 \mathrm{mg} \cdot \mathrm{kg}^{-1}$, respectively) than during the second period (when they were 60.8 and $14.6 \mathrm{mg} \cdot \mathrm{kg}^{-1}$, respectively). Similar results were found in a study of the decomposition of wetland macrophytes. In that study, the mono-P content increased between day 0 (when the mono-P contributed $13 \%$ of the TP content) and day 16 (when the mono-P contributed 26\% of the TP content), then decreased until day 454 , when the mono-P contributed $16 \%$ of the TP content (Cheesman et al., 2010). The Po decomposition process has been found to be affected by environmental conditions, such as the $\mathrm{pH}$ and DO concentration (Wang et al., 2008). The pH, DO concentration, and ORP at the water-sediment interface in our experiment all changed as the duckweed decomposed (Fig. 2). It has been found in previous studies that anaerobic conditions are beneficial to the release of Po from sediment (Ahlgern et al., 2011). The dramatic changes 


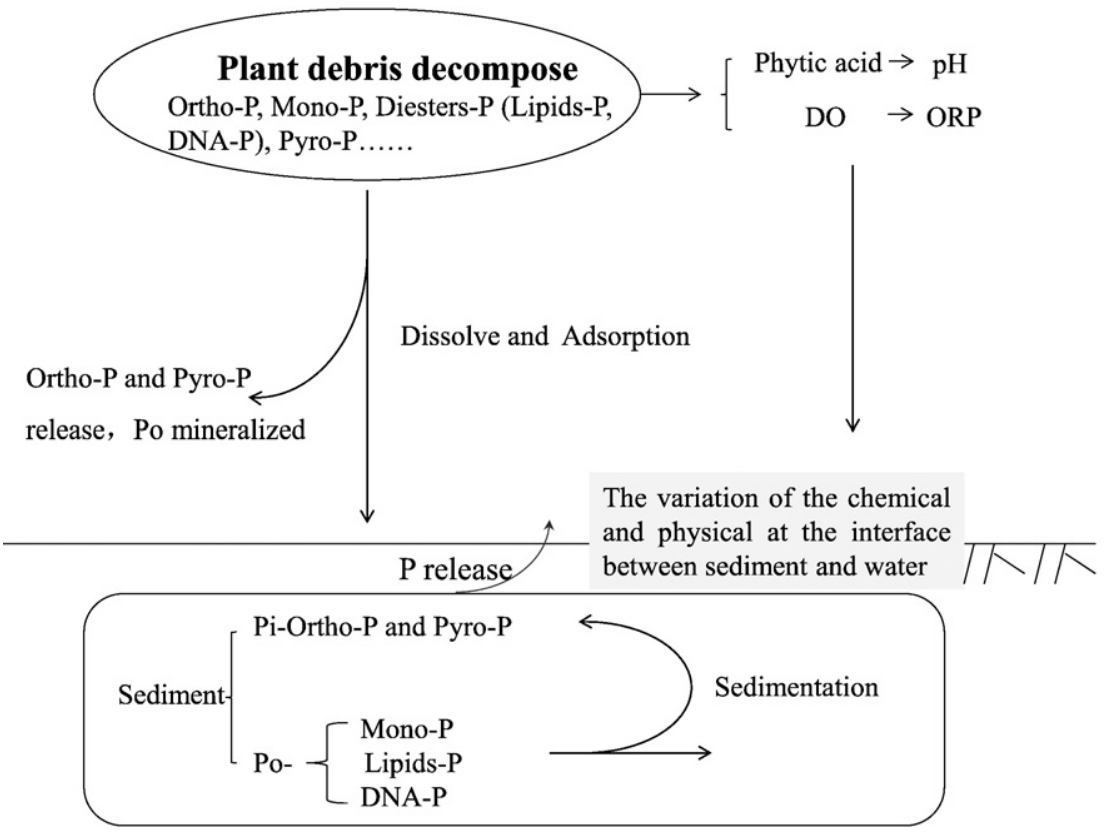

Fig. 6. Conceptual model of plant debris decompose between the surface water and sediment.

in the DO concentration and ORP in the first $7 \mathrm{~d}$ of our study may have been important inducible factors in the release of Po by the decomposing duckweed. During the decay process, however, the environment conditions (the $\mathrm{pH}, \mathrm{DO}$ concentration, and $\mathrm{ORP}$ ) all reached steady state, and the Po may have been mineralized to give Pi.

We deduced that the increase in the ortho-P content of the sediment in the second period had two components, one being the release of ortho-P from the decomposing duckweed debris and the other possibly being Po mineralization. However, low Po mineralization rates (halflives) have been found in previous studies. The mono-P, diester-P, and pyro-P half-lives in Lake Erken in Sweden have been found to be 23, 21 , and $13 \mathrm{y}$, respectively (Ahlgren et al., 2005), and the mono-P, lipid-P, DNA-P, and pyro-P half-lives in Taihu Lake in China have been found to be 27, 14, 12, and $3 \mathrm{y}$, respectively (Ding et al., 2013). Our results indicated that Po could be mineralized quickly when the physicochemical characteristics of the system (e.g., the DO concentration and ORP) change dramatically. ANOVA analysis indicated that myo-inositol phosphate and scyllo-inositol phosphate correlated well $(p>0.05)$ but that the other Po components belonged to the mono-P group, which was found at clearly different concentrations during the first and second periods of the plant debris decomposition process $(p<0.05)$. Further research into Po transformations during the decomposition of plant debris should be performed using appropriate analytical methods, such as $\delta^{18} \mathrm{OP}$ and ${ }^{33} \mathrm{P}$-phosphate (Van Mooy et al., 2015; Gross et al., 2016).

Duckweed is widely distributed in eastern China. Large amounts of duckweed float on the surfaces of rivers, wetlands, and lakes unless the duckweed is collected by people. In view of the high primary production rate for duckweed, very active duckweed decomposition processes must occur in freshwater ecosystems. In fact, large amounts of duckweed are not currently collected because artificial forage has been found to be an ideal alternative to duckweed for feeding poultry. The higher temperatures in summer and fall than in winter and spring mean that plant decomposition occurs more quickly in summer and fall, meaning that the physicochemical characteristics of aquatic systems change more in summer and fall than at other times. Changes in environmental factors will affect the release and transfer of $P$, as shown in Fig. 6. The P released from decomposing plant debris will support the metabolism of aquatic plants, such as algae, and increase the risk of eutrophication occurring. Our results indicate that the decomposition of aquatic plant debris will be a key factor in the release of $\mathrm{P}$ already present in an aquatic system, such as in the sediment and aquatic plants, even when new inputs of external P have decreased. Therefore, it is necessary to regularly collect plant debris from aquatic systems in eastern China to control the release of $\mathrm{P}$ already present in the systems.

\section{Conclusions}

Changes in the physicochemical characteristics of and P concentration in experimental systems while duckweed was decomposing were studied using solution ${ }^{31} \mathrm{P}$ NMR. The $\mathrm{pH}$, DO concentration, and ORP changed dramatically during the experiment, from pH 5.3 to 8.1, 0.17 to $5.08 \mathrm{mg} \cdot \mathrm{L}^{-1}$, and -225.4 to $75.7 \mathrm{mV}$, respectively. The $\mathrm{pH}$, DO concentration, and ORP all first decreased, then increased, and then remained constant. The changes in the physicochemical characteristics affected the decomposition of the plant debris and the release of $P$ to the surface water. The TP concentration in the surface water increased earlier than did the TDP and SRP concentrations because PP and DOP were released by the plant debris.

The decomposition of the duckweed released large amounts of Po, including mono-P and diester-P, from the sediment. The ${ }^{31} \mathrm{P}$ NMR results showed that mono-P was the main component of the Po in the sediment. The decomposition of the duckweed may have caused mono-P and diester-P to be mineralized to give ortho-P and pyro-P. The release of $\mathrm{P}$ induced by the decomposition of plant debris may be a major source of $P$ in aquatic systems even when external sources of $P$ are not present.

\section{Acknowledgments}

This work was supported by the National Natural Science Foundation of China (grant no. 21507146), the National Major Science and Technology Program for Water Pollution Control and Treatment (grant no. 2015ZX07203-011), and the The Youth Innovation Promotion Association CAS (Wenzhong Tang, 2017059).

\section{Appendix A. Supplementary data}

Supplementary data to this article can be found online at http://dx. doi.org/10.1016/j.scitotenv.2017.01.103. 


\section{References}

Ahlgern, J., Reitzel, K., De Brabandere, H., Gogoll, A., Rydin, E., 2011. Release of organic P forms from lake sediments. Water Res. 45, 565-572.

Ahlgren, J., Tranvik, L., Gogoll, A., Waldebäck, M., Markides, K., Rydin, E., 2005. Sediment depth attenuation of biogenic phosphorus compounds measured by ${ }^{31} \mathrm{P}$ NMR. Environ. Sci. Technol. 39, 867-872.

An, W.C., Li, X.M., 2009. Phosphate adsorption characteristics at the sediment-water interface and phosphorus fractions in Nansi Lake, China, and its main inflow rivers. Environ. Monit. Assess. 148, 1-4.

Aspila, K.I., Agemian, H., Chau, A.S.Y., 1976. A semi-automated method for the determination of inorganic organic and total phosphate in sediments. Analyst 101, 187-197.

Benitez-Nelson, C.R., Buesseler, K.Q., 1999. Variability of inorganic and organic phosphorus turnover rates in the coastal ocean. Nature 398, 502-505.

Bjorkman, K.M., Karl, D.M., 1994. Bioavailability of inorganic and organic phosphorus compounds to natural assemblages of microorganisms in Hawaiian coastal waters Mar. Ecol. Prog. Ser. 111, 265-273.

Cade-Menun, B.J., 2005. Characterizing phosphorus in environmental and agricultural samples by ${ }^{31} \mathrm{P}$ nuclear magnetic resonance spectroscopy. Talanta 66, 359-371.

Cade-Menun, B.J., Liu, C.W., Nunlist, R., McColl, J.G., 2002. Soil and litter phosphorus-31 nuclear magnetic resonance spectroscopy: extracts, metals, and phosphorus relaxation times. J. Environ. Qual. 31, 457-465.

Cade-Menun, B.J., Navaratnam, J.A., Walbridge, M.R., 2006. Characterizing dissolved and particulate phosphorus in water with ${ }^{31} \mathrm{P}$ nuclear magnetic spectroscopy. Environ. Sci. Technol. 40, 7874-7880.

Carpenter, S.R., 2008. Phosphorus control is critical to mitigating eutrophication. Proc. Natl. Acad. Sci. 105, 11039-11040.

Cheesman, A.W., Turnar, B.L., Inglett, P.W., Reddy, K.R., 2010. Phosphorus transformations during decomposition of wetland macrophytes. Environ. Sci. Technol. 44, 9265-9271.

Chróst, R.J., 1991. Environmental control of the synthesis and activity of aquatic microbia ectoenzymes. In: Chróst, R.J. (Ed.), Microbial Enzymes in Aquatic Environments. Springer-Verlag, New York, pp. 29-59.

Corstanje, R., Reddy, K.R., Portier, K.M., 2006. Typha latifolia and Cladium jamaicense litter decay in response to exogenous nutrient enrichment. Aquat. Bot. 84, 70-78.

DeBusk, W.F., Reddy, K.R., 2005. Litter decomposition and nutrient dynamics in a phosphorus enriched everglades marsh. Biogeochemistry 75, 217-240.

Ding, S., Xu, D., Bai, X.L., Yao, S.C., Fan, C.X., Zhang, C.S., 2013. Speciation of organic phosphorus in a sediment profile of Lake Taihu II. Molecular species and their depth attenuation. J. Environ. Sci. 25, 925-932.

Du, S.T., Shentu, J.L., Luo, B.F., Shamsi, I.H., Lin, X.Y., Zhang, Y.S., Jin, C.W., 2011. Facilitation of phosphorus adsorption onto sediment by aquatic plant debris. J. Hazard. Mater. $191,212-218$

Gross, A., Turner, B.L., Goren, T., Berry, A., Angert, A., 2016. Tracing the sources of atmospheric phosphorus deposition to a tropical rain forest in Panama using stable oxygen isotopes. Environ. Sci. Technol. 50, 1147-1156.

Hupfer, M., Gächter, R., Ruegger, H., 1995. Polyphosphate in lake sediments: ${ }^{31}$ P NMR spectroscopy as a tool for its identification. Limnol. Oceanogr. 40, 610-617.

Hupfer, M., Rübe, B., Schmieder, P., 2004. Origin and diagenesis of polyphosphate in lake sediments: a ${ }^{31}$ P NMR study. Limnol. Oceanogr. 49, 1-10.

Jin, X., Xu, Q., Huang, C., 2005. Current status and future tendency of lake eutrophication in China. Sci. China Ser. C Life Sci. 48, 948-954.

Kagaloua, I., Papastergiadoub, E., Leonardosa, I., 2008. Long term changes in the eutrophication process in a shallow Mediterranean lake ecosystem of W. Greece: response after the reduction of external load. J. Environ. Manag. 87, 497-506.

Kraal, P., Burton, E.D., Rose, A.L., Cheetham, M.D., Bush, R.T., Sullivan, L.A., 2013. Decoupling between water column oxygenation and benthic phosphate dynamics in a shallow eutrophic estuary. Environ. Sci. Technol. 47, 3114-3121.

Liu, J., Hu, Y.F., Yang, J.J., Abdi, D., Cade-Menun, B.J., 2015. Investigation of soil legacy phosphorus transformation in long term agriculture field using sequential fractionation, P K-edge XANES and solution P NMR spectroscopy. Environ. Sci. Technol. 49, 168-176.

Maavara, T., Parsons, C.T., Ridenour, C., Stojanovic, S., Bürr, H.H., Powley, H.R., Cappellen, P.V., 2015. Global phosphorus retention by river damming. Proc. Natl. Acad. Sci. $112,15603-15608$

McDowell, R.W., Stewart, I., Cade-Menun, B.J., 2006. An examination of spin-lattice relaxation times for analysis of soil and manure extracts by liquid state phosphorus-31 nuclear magnetic resonance spectroscopy. J. Environ. Qual. 35, 293-302.

Nyenje, P.M., Foppen, J.W., Uhlenbrook, S., Kulabako, R., Muwanga, A., 2010. Eutrophication and nutrient release in urban areas of sub-Saharan Africa-a review. Sci. Total Environ. 408, 447-455.

Pant, H.K., Reddy, K.R., 2001. Phosphorus sorption characteristics of estuarine sediments under different redox conditions. J. Environ. Qual. 30, 1474-1480.

Pernet-Coudrier, B., Qi, W.X., Liu, H.J., Müller, B., Berg, M., 2012. Sources and pathway of nutrients in the semi-arid region of Beijing-Tianjin, China. Environ. Sci. Technol. 46, 5294-5301.

Reynolds, C.S., 2008. Phosphorus recycling in lakes: evidence from large limnetic enclosures for the importance of shallow sediments. Freshw. Biol. 35, 623-645.

Schindler, D.W., Carpenter, S.R., Chapra, S.C., Hecky, R.E., Orihel, D.M., 2016. Reducing phosphorus to curb eutrophication is a success. Environ. Sci. Technol. 50, 8923-8929.

Schneider, K.D., Cade-Menun, B.J., Lynch, D.H., Voroney, R.P., 2016. Soil phosphorus form organic and conventional forage fields. Soil Sci. Soc. Am. J. 80, 328-340.

Smith, V.H., Schindler, D.W., 2008. Eutrophication science: where do we go from here? Trends Ecol. Evol. 24, 201-207.

Sulu-Gambari, F., Seitaj, D., Meysman, F.J.R., Schauer, R., Polerecky, L., Slomp, C.P., 2015. Cable bacteria control iron - phosphorus dynamics in sediments of a coastal hypoxic basin. Environ. Sci. Technol. 50, 1227-1233.

Suzumura, M., Kamatani, A., 1995. Mineralization of inositol hexaphosphate in aerobic and anaerobic marine sediments: implications for the phosphorus cycle. Geochim. Cosmochim. Acta 59, 1021-1026.

Turner, B.L., Mahieu, N., Condron, L.M., 2003a. Phosphorus-31 nuclear magnetic resonance spectral assignments of phosphorus compounds in soil NaOH-EDTA extracts. Soil Sci. Soc. Am. J. 67, 497-510.

Turner, B.L., Mahieu, N., Condron, L.M., 2003b. The phosphorus composition of temperate pasture soils determined by $\mathrm{NaOH}-\mathrm{EDTA}$ extraction and solution ${ }^{31} \mathrm{P}$ NMR spectroscopy. Org. Geochem. 34, 1199-1210.

Turner, B.L., Cade-Menun, B.J., Condron, L.M., Newman, S., 2005a. Extraction of soil organic phosphorus. Talanta 66, 294-306

Turner, B.L., Frossard, E., Baldwin, D., 2005b. Organic Phosphorus in the Environment. CABI Publishing.

Valiela, I., Teal, J.M., Allen, S.D., Van Etten, R., Goehringer, D., Volkmann, S., 1985. Decomposition in salt marsh ecosystems: the phases and major factors affecting the disappearance of above-ground organic matter. J. Exp. Mar. Biol. Ecol. 89, 29-54.

Van Mooy, B.A.S., Krupke, A., Dyhrman, S.T., Fredricks, H.F., Frischkorn, K.R., Ossolinski, J.E., Repeta, D.J., Rouco, M., Seewald, J.D., Sylva, S.P., 2015. Major role of planktonic phosphate reduction in the marine phosphorus redox cycle. Science 348, 783-785.

Vörösmarty, C.J., McIntyre, P.B., Gessner, M.O., Dudgeon, D., Prusevich, A., Green, P., et al. 2010. Global threats to human water security and river biodiversity. Nature 467, 555-561.

Wang, S.R., Jin, X.C., Bu, Q.Y., Jiao, L.X., Wu, F.C., 2008. Effects of dissolved oxygen supply level on phosphorus release from lake sediments. Colloids Surf. A Physicochem. Eng. Asp. 316, 245-252.

Zhang, W.Q., Shan, B.Q., Zhang, H., Tang, W.Z., 2013. Assessment of preparation methods for organic phosphorus analysis in phosphorus-polluted Fe/Al-rich Haihe River sediments using solution ${ }^{31}$ P NMR. PLoS One 8, e76525.

Zhu, Y.R., Ma, R., Liu, Q.D., Rong, Q.Q., Yang, L., Wang, Y., 2010. Several important research advances on duckweed. Bull. Biol. 45, 4-6. 